\title{
Determination of potential risk of heat stress of cattle in four locations of Central and Southern Chile
}

\author{
Determinación del riesgo potencial de estrés térmico del ganado bovino \\ en cuatro localidades del centro y sur de Chile \\ RA Arias ${ }^{a^{*}}$ TL Mader ${ }^{b}$ \\ aEscuela de Agronomía, Facultad de Recursos Naturales Universidad Católica de Temuco, Temuco, Chile. \\ ${ }^{b}$ Department of Animal Science, University of Nebraska-Lincoln, Lincoln, USA.
}

\begin{abstract}
RESUMEN
Datos climáticos del periodo diciembre a febrero de los años 1999 al 2007 provenientes de estaciones meteorológicas situadas en Curicó, Chillán, Temuco y Osorno fueron utilizados para calcular un índice temperatura-humedad ajustado por el efecto del viento y de la radiación (THI ${ }_{\text {adj-max }}$ ). Las variables climáticas utilizadas para calcular este índice incluyeron: velocidad del viento, temperatura máxima del aire, humedad relativa y un valor estimado de la radiación solar. Cuando los valores de THI ${ }_{\text {adj-max }}$ fueron superiores a 75, estos días fueron considerados como indicadores de "alerta" y riesgo potencial de estrés térmico en el ganado. Adicionalmente, el impacto en la producción animal fue estimado sobre la base de pérdidas potenciales de producción de leche para cada localidad, utilizando dos ecuaciones para su estimación. Las localidades de la región central, Curicó y Chillán, presentaron valores promedios de $\mathrm{THI}_{\text {adj-max }}$ similares (79,4 y 79,1, respectivamente), pero ambos superiores a las de la región sur (Temuco y Osorno 77,1 y 68,1, respectivamente; $\mathrm{P}<0,05)$. La probabilidad de días con $\mathrm{THI}_{\text {adj-max }}>75$ fue mayor en la región central. Asimismo, la producción de leche mostró un mayor potencial de pérdidas en las regiones centrales de Chile (1,5 a 4,3 y 1,2 a 3,6 $\mathrm{L}^{*} \mathrm{vaca}^{-1 *} \mathrm{~d}^{-1}$ para Curicó y Chillán, respectivamente). Por otra parte, las regiones del sur, Temuco y Osorno, presentaron menores pérdidas potenciales $\left(0,9\right.$ a 2,6 y 0,1 a $0,6 \mathrm{~L}^{*} \mathrm{vaca}^{-1 *} \mathrm{~d}^{-1}$, respectivamente). En conclusión, el riesgo potencial de estrés térmico para el ganado bovino es mayor en Curicó y Chillán, es moderado en Temuco, y es mínimo en Osorno. Finalmente, la cuantificación del impacto directo que tiene el clima sobre la productividad y el bienestar de los bovinos en Chile necesita ser estudiada.
\end{abstract}

Key words: heat stress, risk, cattle, Chile.

Palabras clave: estrés térmico, riesgo, ganado, Chile.

\section{INTRODUCTION}

Environmental effects have been widely recognized as factors affecting heat balance, productivity and reproductive efficiency in beef and dairy cattle (Igono et al 1987, Birkelo and Johnson 1993, Amundson et al 2006). There are certain periods of the year when cattle suffer some degree of stress due to a combination of factors such as handling, nutrition and environment. If the period of environmental stress is short, a decrease in milk production is observed in dairy cattle, but negative effects of weather generally go unnoticed in beef cattle because animal weight is not recorded daily. On the other hand, if the period of environmental stress is long, cattle can suffer serious consequences, affecting energy requirements and partition, dry matter intake, average daily gain, conception rate, and in extreme cases it can cause the death of cattle (Johnson 1986, Mader et al 1997, Amundson et al 2006). During the last 10 years, heat stress events in the USA have produced significant losses to the livestock

Accepted: 26.08.2009.

* Casilla 15-D, Temuco, Chile; rarias@uctemuco.cl industry. Annual losses were estimated to be $\$ 897$ and $\$ 369$ million for the dairy and the beef industries, respectively (St-Pierre et al 2003). Numerous studies have been conducted to identify the thresholds at which cattle begin to suffer from the negative effects of weather and to determine when to apply adequate mitigation actions. For almost fourty years the temperature humidity index (THI), a single value representing the combined effects of air temperature and humidity (Thom 1959), has been used as indicator of thermal stress in man and livestock. Recently the THI has been adjusted by solar radiation and wind speed, two important factors affecting thermal balance in cattle (Mader et al 2006).

In addition, animal well-being is acquiring greater relevance around the world and will be considered as an important factor in the commercialization of beef and dairy products. In Chile, there is limited information available regarding the impact of environmental effects; particularly heat stress on production and reproduction of livestock. The geographical and climatological characteristics of Chile, make it possible to hypothesize that a greater impact of heat stress could be expected in the Central regions of the country, especially on cattle with high levels of production. Therefore, the objective of this paper was to assess the risk of heat stress in four locations of Central and Southern 
Chile using an adjusted temperature humidity index, to provide baseline information for further research.

\section{MATERIAL AND METHODS}

This study is a first approach to assess the impact of environmental factors on cattle in Chile. For this, a set of different meteorological data from locations of Central and Southern Chile (Curicó, Chillán, Temuco, and Osorno) and the estimated milk production losses were used as reference. Milk production losses were chosen as an example of the impacts of weather on cattle productivity. Meteorological data of these locations were used to calculate the THI and a maximum adjusted THI (THI ${ }_{\text {adj-max }}$ ), two thermal comfort indices. Detailed geographical locations of the weather stations and the characteristics of the meteorological series data used herein are presented in table 1. Environmental data correspond to the summer period for each year (December through February). Depending of the location of study, data were gathered for the period 1999-2007, and included air temperature $\left(T_{a}\right)$, maximum and minimum temperature ( $\mathrm{T}_{\text {max }}$ and $\mathrm{T}_{\text {min }}$, respectively), wind speed (WS), and relative humidity (RH). The thermal indices THI and $\mathrm{THI}_{\text {adj }}$ were calculated as follows:

$$
\mathrm{THI}=0.8 * \mathrm{~T}_{\mathrm{a}}+(\mathrm{RH} / 100) *\left(\mathrm{~T}_{\mathrm{a}}-14.4\right)+46.4 ;(\text { Mader }
$$
2003) (1)

$$
\mathrm{THI}_{\mathrm{adj}}=4.51+\mathrm{THI}-(\mathrm{WS} * 1.992)+(0.0068 * \mathrm{SR}) ;
$$

(Mader et al 2006)

Equation 2 includes the variable solar radiation (SR), which was not available in the dataset. Therefore, in order to calculate the $\mathrm{THI}_{\text {adj }}$, $\mathrm{SR}$ was assumed as a constant of $550 \mathrm{~W}^{*} \mathrm{~h}^{-1 *} \mathrm{~m}^{-2}$ for all the locations. This value corresponds to a mean value for daytime during the summer period in the city of Temuco ${ }^{1}$ (08:00 to 20:00 h). These data were used as reference due to its reliability and availability, and because Temuco is centrally located in relation to the other places.

\section{STATISTICAL ANALYSIS}

Data from each location were summarized across years in order to obtain the mean values for $\mathrm{THI}_{\mathrm{adj}}$ and maximum $\mathrm{THI}_{\mathrm{adj}}$. Maximum $\mathrm{THI}_{\mathrm{adj}}$ was calculated using the maximum air temperature instead of mean air temperature. Additionally, the number of days with THI values on the categories of the Livestock Weather Safety Index (LCI 1970) was estimated. The Livestock Weather Safety Index (LWSI) presented in table 2, was developed in the 70's as a practical tool to classify the combined intensity of temperature and humidity into four categories. Experience over time suggested that the THI-based

Based on information provided by the weather station of the Universidad Católica de Temuco, Chile.
LWSI was a valuable tool for producers, even though it lacked recognition of the effects of thermal radiation and wind speed. Warnings with respect to these categories, were issued by the United States Weather Bureau to alert producers from potential heat stress conditions (Nienaber and Hahn 2007). The probability of occurrence of days in each category was calculated and this information was used to build a contingency table and a mosaic plot. The relationship between risk of potential heat stress and the locations was assessed with a Chi-square test, using the software JMP® version 5.0.1.2 for Mac (SAS Institute Inc, Cary, NC). In this study the location was the explanatory variable and the number of days in each category of the LWSI was the response variable. Therefore, the conditional distributions of LWSI categories given a particular location were tested. Subsequently, a correspondence analysis was conducted to identify the relationship among locations and LWSI categories.

Finally, the impact of potential heat stress was conducted by estimating decrease of milk production. Estimated milk production losses were calculated using two different equations developed in Argentina and Tunisia. These equations were chosen because the latitude at which the equations were obtained is comparable with the locations herein evaluated (ranging from 35 to 40 degrees). The Argentinean equation was developed by Valtorta $e t$ al (1999) and reported by de la Casa and Ravelo (2003), milk production $\left(\mathrm{L}^{*} \mathrm{cow}^{-1 *} \mathrm{day}^{-1}\right)=40.51-0.2524 * \mathrm{THI}$. The Tunisian equation was developed by Bouranoui et al (2002), milk production $=47.729-0.4129 * \mathrm{THI}$, expressed in $\left(\mathrm{kg}^{*} \mathrm{cow}^{-1 *} \mathrm{day}^{-1}\right)$. In this study, the maximum adjusted THI $\left(\mathrm{THI}_{\text {adj-max }}\right)$ was used instead of the THI in order to estimate the potential risk under extreme weather conditions for each location. The criterion used to estimate milk production losses was established when $\mathrm{THI}_{\text {adj-max }}$ was greater than 69 and 75 for the Tunisian and Argentinean equations, respectively.

\section{RESULTS}

Mean values for environmental variables and thermal indices by month and location for the summer are presented in table 3. Mean ambient temperatures and maximum ambient temperatures were significantly greater for the Central locations and lower for the Southern locations $(\mathrm{P}<0.05)$, but mean relative humidity was significantly greater in the Southern locations, such as Osorno and Temuco. Mean THI values were significantly lower in Temuco followed by Osorno, Chillán and Curicó $(\mathrm{P}<0.05)$. However, the $\mathrm{THI}_{\text {adj }}$ was greater in Temuco than in Osorno $(\mathrm{P}<0.05)$. The difference between THI and $\mathrm{THI}_{\text {adj }}$ could be explained by the higher mean wind speed recorded in Osorno. On the other hand, $\mathrm{THI}_{\text {adj-max }}$ was similar between Curicó and Chillán, but both were greater than Temuco and Osorno $(\mathrm{P}<0.05)$. 
Table 1. Geographical location of weather stations and series characteristics of the dataset used.

Ubicación geográfica de las estaciones climáticas y características de las series de datos utilizadas.

\begin{tabular}{lccccc}
\hline \multirow{2}{*}{$\begin{array}{c}\text { Weather station } \\
\text { (ICAO Codex) }\end{array}$} & Latitude & Longitude & $\begin{array}{c}\text { Altitude } \\
(\text { amsl) }\end{array}$ & Years considered & $\mathrm{N}^{\circ}$ missed days by variable \\
\cline { 2 - 6 } & $-34^{\circ} 96$ & $-71^{\circ} 21$ & 228 & $2000-2007$ & $136^{*}$ and $140^{\dagger}$ \\
\hline Curicó (856290-SCIC) & $-36^{\circ} 58$ & $-72^{\circ} 03$ & 124 & $2002-2007$ & 153 \\
Chillán (856720-SCCH) & $-38^{\circ} 76$ & $-72^{\circ} 63$ & 114 & $1999-2007$ & 3 \\
Temuco (857430-SCTC) & $-40^{\circ} 60$ & $-73^{\circ} 05$ & 58 & $2000-2007$ & $352^{*}$ and $354^{\dagger}$ \\
Osorno (857820) & &
\end{tabular}

* Mean air temperature, maximum and minimum air temperatures. ${ }^{\dagger}$ Relative humidity. Absence of superscripts indicates that the number is valid for all the variables collected.

Table 2. Livestock Safety Weather Index for cattle. Índice de riesgo de estrés térmico para el ganado.

\begin{tabular}{lc}
\hline Category & THI value \\
\hline Normal & $<74$ \\
Alert & $75 \leq \mathrm{THI} \leq 78$ \\
Danger & $79<\mathrm{THI} \leq 83$ \\
Emergency & $>84$ \\
\hline
\end{tabular}

(LCI 1970).

Figure 1 shows the values of the $\mathrm{THI}_{\text {adj-max }}$ by day, month, and location. In general, during December the $\mathrm{THI}_{\text {adj-max }}$ values were lower than in January and February across all the locations, especially during the first days of the month. A similar pattern of $\mathrm{THI}_{\text {adj-max }}$ was observed for Chillán and Temuco, but it was less clear in Curicó and Osorno. During February, the THI adj-max tended to be higher in the Southern locations (Temuco and Osorno), but no major differences were observed in Curicó and Chillán.
Figure 2 shows a mosaic plot that relates the risk of heat stress and location. The proportion in the $\mathrm{x}$-axis represents the relative size of the locations dataset, whereas the proportions shown on the right $y$-axis represent the relative sizes of each category for the combined locations. The scale of the left y-axis shows the probability of occurrence of each category by location, with the whole axis representing a probability of 1 . When the probability of days by category was analyzed independent of location, a greater number of days in the Danger category was observed (0.38), followed by days classified as Normal (0.29), Alert (0.23), and Emergency (0.09). Osorno was the location with the greater proportion of missing data, whereas Temuco had the lowest amount of missing values (also showed numerically in table 1). The mosaic plot also shows a relationship between risk of heat stress and location ( $\mathrm{P}-\mathrm{ChiSq}<0.001$ ). Chillán showed a greater probability of days in the Danger category (0.46), but similar probabilities of days in categories Normal, Alert and Emergency (around

Table 3. Mean environmental values for location and month.

Valores promedio de las variables ambientales por localidad y mes.

\begin{tabular}{lcccccccccc}
\hline Locality & $\mathrm{AT}$ & $\mathrm{AT}_{\max }$ & $\mathrm{AT}_{\min }$ & $\mathrm{RH}$ & $\mathrm{PP}$ & $\mathrm{WS}$ & $\mathrm{THI}$ & $\mathrm{THI}_{\text {adj-min }}$ & $\mathrm{THI}_{\text {adj }}$ & $\mathrm{THI}_{\text {adj-max }}$ \\
\hline Curicó & $23.1^{\mathrm{a}}$ & $29.9^{\mathrm{a}}$ & $12.5^{\mathrm{a}}$ & $49.1^{\mathrm{c}}$ & $0.2^{\mathrm{c}}$ & $12.0^{\mathrm{b}}$ & $69.0^{\mathrm{a}}$ & $57.0^{\mathrm{b}}$ & $72.3^{\mathrm{a}}$ & $79.4^{\mathrm{a}}$ \\
$\quad$ December & 22.5 & 29.0 & 12.2 & 49.3 & 0.1 & 12.8 & 68.3 & 56.2 & 69.4 & 77.8 \\
January & 23.8 & 30.8 & 13.1 & 48.1 & 0.1 & 12.5 & 69.9 & 57.6 & 73.3 & 80.2 \\
$\quad$ February & 22.9 & 30.0 & 12.1 & 49.9 & 0.2 & 10.7 & 68.8 & 57.3 & 74.2 & 80.4 \\
Chillán & $21.9^{\mathrm{b}}$ & $28.7^{\mathrm{b}}$ & $11.2^{\mathrm{b}}$ & $50.1^{\mathrm{c}}$ & $0.8^{\mathrm{bc}}$ & $10.0^{\mathrm{c}}$ & $67.6^{\mathrm{b}}$ & $56.4^{\mathrm{b}}$ & $70.0^{\mathrm{b}}$ & $79.1^{\mathrm{a}}$ \\
December & 20.3 & 26.1 & 10.7 & 54.9 & 0.9 & 10.0 & 65.8 & 55.6 & 68.2 & 76.4 \\
January & 23.0 & 30.0 & 12.0 & 48.4 & 0.1 & 10.5 & 68.9 & 57.2 & 71.0 & 80.3 \\
February & 22.5 & 30.1 & 10.9 & 46.8 & 1.3 & 9.3 & 68.1 & 56.5 & 70.8 & 80.8 \\
Temuco & $15.7^{\mathrm{d}}$ & $24.8^{\mathrm{c}}$ & $8.5^{\mathrm{c}}$ & $69.9^{\mathrm{a}}$ & $1.2^{\mathrm{ab}}$ & $8.5^{\mathrm{d}}$ & $59.8^{\mathrm{d}}$ & $52.9^{\mathrm{c}}$ & $63.4^{\mathrm{c}}$ & $77.1^{\mathrm{b}}$ \\
December & 14.6 & 22.6 & 8.0 & 72.4 & 1.4 & 8.8 & 58.2 & 51.8 & 61.8 & 73.9 \\
January & 16.1 & 25.4 & 8.6 & 68.6 & 1.0 & 8.9 & 60.6 & 53.3 & 64.0 & 77.9 \\
February & 16.3 & 26.5 & 8.8 & 68.7 & 1.1 & 7.8 & 60.6 & 53.6 & 64.6 & 79.7 \\
Osorno & $17.3^{\mathrm{c}}$ & $21.4^{\mathrm{d}}$ & $9.0^{\mathrm{c}}$ & $67.0^{\mathrm{b}}$ & $1.8^{\mathrm{a}}$ & $14.8^{\mathrm{a}}$ & $62.1^{\mathrm{c}}$ & $62.1^{\mathrm{a}}$ & $62.1^{\mathrm{d}}$ & $68.1^{\mathrm{c}}$ \\
December & 16.1 & 19.5 & 8.5 & 67.8 & 2.1 & 16.1 & 60.4 & 59.7 & 59.7 & 64.7 \\
January & 17.5 & 21.5 & 8.9 & 65.9 & 2.1 & 16.4 & 62.3 & 61.5 & 61.5 & 67.3 \\
February & 18.4 & 23.3 & 9.5 & 67.2 & 1.2 & 11.6 & 63.6 & 65.4 & 65.4 & 72.7 \\
\hline
\end{tabular}

Different superscripts means statistical differences at $\mathrm{P}<0.05$ among locations (Tukey-Kramer HSD).

$\mathrm{AT}=$ ambient temperature $\left({ }^{\circ} \mathrm{C}\right), \mathrm{AT}_{\max }$ and $\mathrm{AT}_{\min }=$ maximum and minimum air temperature $\left({ }^{\circ} \mathrm{C}\right), \mathrm{RH}=$ relative humidity $(\%), \mathrm{PP}=$ precipitation $(\mathrm{cm})$, $\mathrm{WS}=$ wind speed $\left(\mathrm{km}^{*} \mathrm{~h}^{-1}\right), \mathrm{THI}_{\text {adj }}=$ adjusted $\mathrm{THI}, \mathrm{THI}_{\text {adj-max }}$ and $\mathrm{THI}_{\text {adj-min }}=$ maximum and minimum adjusted THI. 


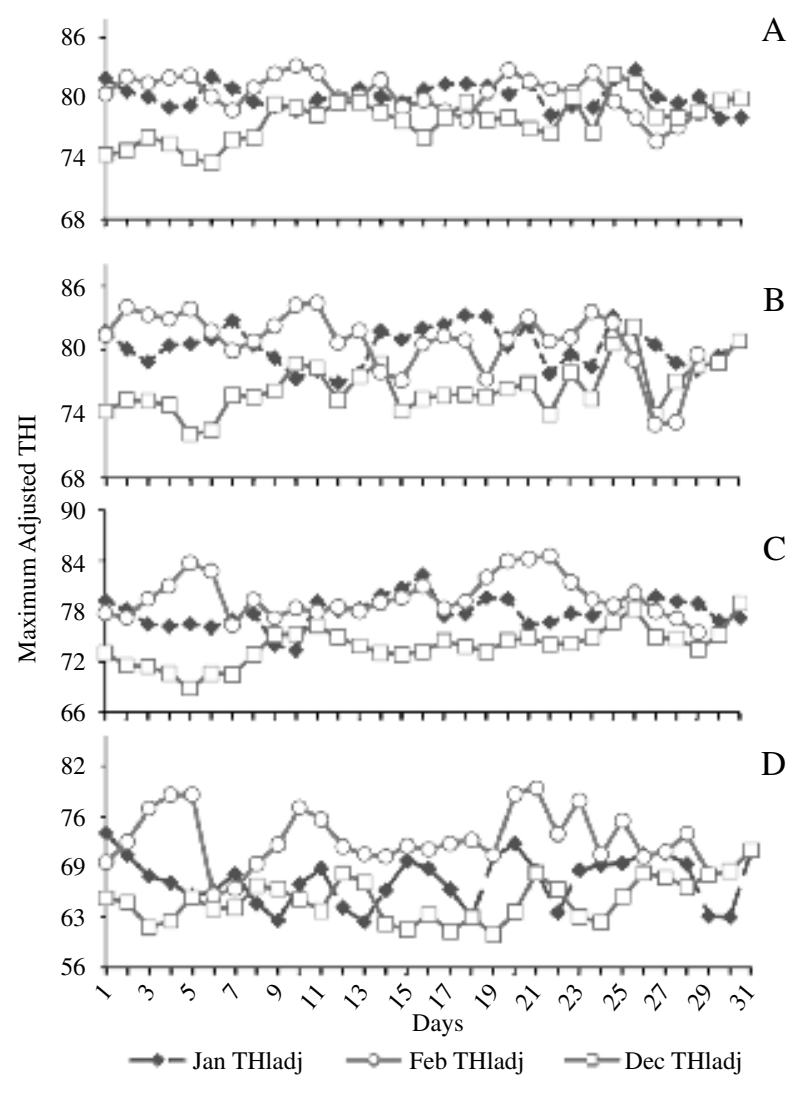

Figure 1. Daily $\mathrm{THI}_{\text {adj-max }}$ by location and month. A=Curicó, $\mathrm{B}=$ Chillán, $\mathrm{C}=$ Temuco, and $\mathrm{D}=$ Osorno.

Valores diarios del $\mathrm{THI}_{\text {adj-max }}$ por localidad y mes. A=Curicó, $\mathrm{B}=$ Chillán, $\mathrm{C}=$ Temuco, and $\mathrm{D}=$ Osorno.

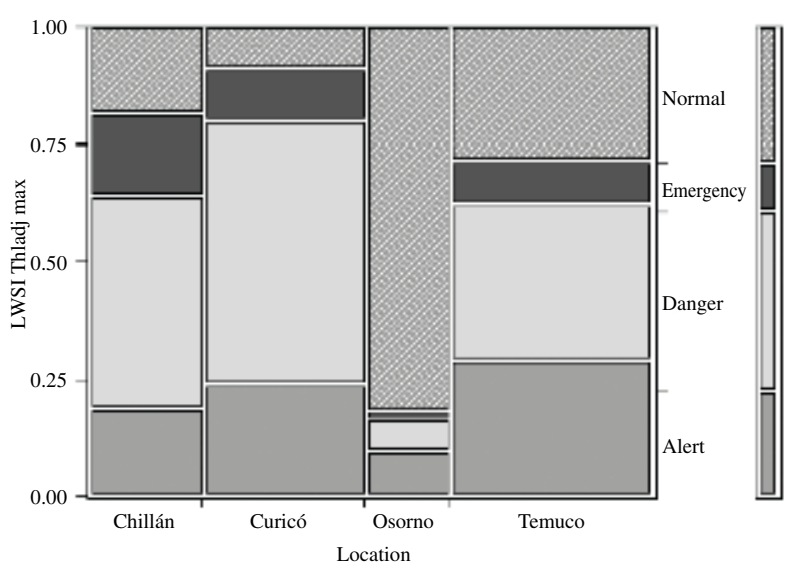

Figure 2. Mosaic plot for category of Livestock Weather Safety Index by locations in Central and Southern Chile.

Gráfico de mosaico por categoría de índice de riesgo de estrés térmico por localidad en el centro y sur de Chile.

0.18). Likewise, Curicó showed greater probabilities of days in the Danger and Alert categories (0.56 and 0.24 each), but lower probabilities for Emergency and Normal categories. Temuco showed similar probabilities among Normal, Alert and Danger categories (around 0.30), with a lower probability of days in the category Emergency (0.09). Finally, Osorno showed the greatest probability of days considered as Normal (0.82) and a very low probability of days considered as Emergency (0.02).

Figure 3 shows the correspondence analysis plot, which examines the relationship between locations of interest and the categories of risk of heat stress (defined in table 2). From the above plot, it is observed that Chillán and Curicó are most closely associated with days in Danger and Emergency categories. Temuco showed a higher probability of occurrence of days in the Alert category, whereas Osorno was mostly associated with days on Normal category.

The evaluation of the impact of the environmental conditions on animal production was done by means of the estimation of milk production losses, which were calculated by two different equations that use the THI as predictor. Potential milk production losses were estimated for each day and summarized for one summer month that represents the mean values for the December to February period. Figure 4 shows these potential milk losses for each equation, location and day of a month. From this analysis, it is clear that the Central regions would potentially have greater milk production losses (1.5 to 4.3 and 1.2 to 3.1 $\mathrm{L}^{*} \operatorname{cow}^{-1 *} \mathrm{~d}^{-1}$ for Curicó and Chillán, respectively). Temuco would present moderate losses, whereas lower losses would be expected for Osorno ( 0.9 to 2.6 and 0.1 to 0.6 $\mathrm{L}^{*} \operatorname{cow}^{-1 *} \mathrm{~d}^{-1}$, respectively).

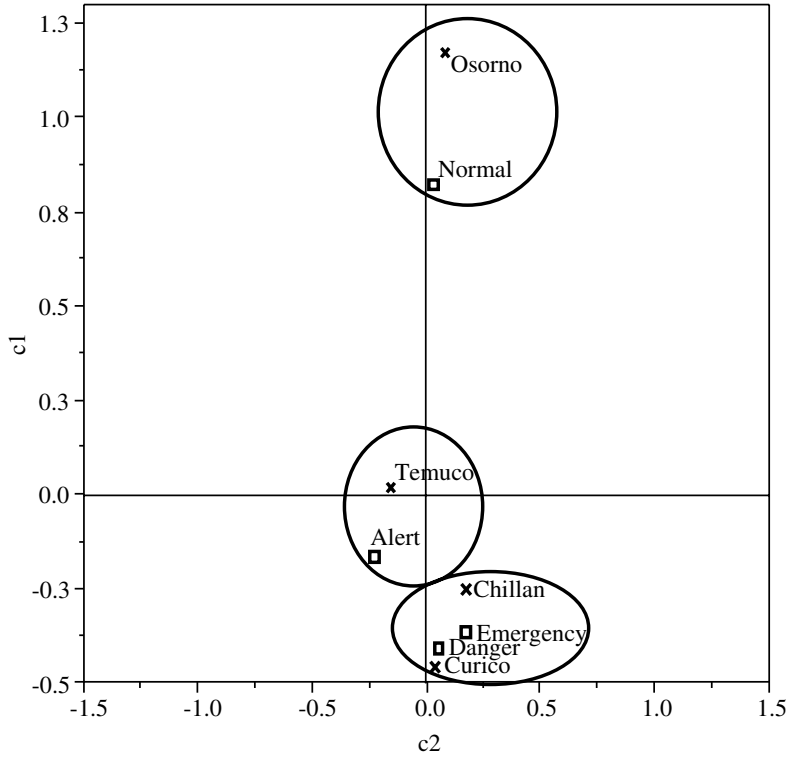

Figure 3. Correspondence analysis for locations and the Livestock Weather Safety Index categories. The two axes (c1 and c2) are the two first dimensions of the correspondence analysis solution.

Análisis de correspondencias para localidades y categorías del Índice de Estrés Térmico del Ganado. Los dos ejes (c1 y c2) corresponden a las dos primeras dimensiones de la solución del análisis de correspondencia. 


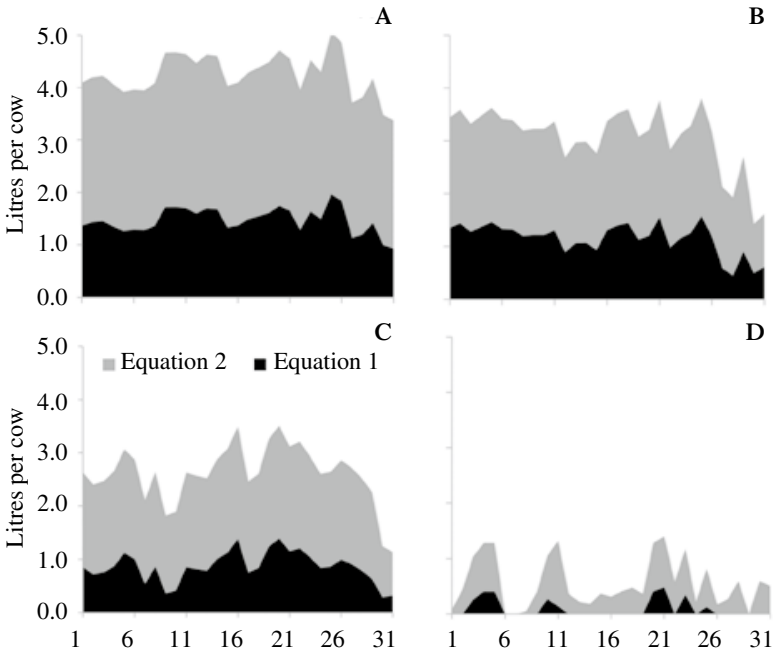

Figure 4. Potential milk production losses per day due to heat stress in Central and Southern Chile, where equation 1 is MP = 40,51 - 0,2524 THI (de la Casa and Ravelo, 2002); and equation 2 is $\mathrm{MP}=47,722-0,4129 \mathrm{THI}$ (Bouraoui et al, 2003). $\mathrm{A}=$ Curicó, $\mathrm{B}=$ Chillán, $\mathrm{C}=$ Temuco and $\mathrm{D}=$ Osorno.

Pérdidas potenciales de producción de leche por día debido a estrés térmico en el centro y sur de Chile, donde ecuación 1 es MP $=40,51-0,2524$ THI (de la Casa y Ravelo, 2003); y ecuación 2 es MP $=47,722-0,4129$ THI (Bouraoui et al, 2003). A= Curicó, $B=$ Chillán, $\mathrm{C}=$ Temuco and $\mathrm{D}=$ Osorno.

\section{DISCUSSION}

Currently, only a few studies conducted in Chile have reported effects of environmental factors on performance of dairy cattle. No reports have been published regarding the effects of environmental factors or heat stress during the summer in beef cattle. This demonstrates the lack of information regarding these topics in the country. However, animal well-being and environmental management are acquiring greater relevance. The negative effects of extreme summer weather conditions on productivity and animal well-being around the world have been widely recognized and summarized by Arias et al (2008), Collier et al (2006), and Kadzere et al (2002).

Results herein presented indicate great differences between the locations observed in terms of risk of potential heat stress. The potential risk of heat stress of cattle seems to be greater in Curicó and Chillán than in Temuco and Osorno. Cattle of the central regions of Chile could be experiencing unfavorable climatic conditions, which added to the intensive production systems characteristics of these regions, would conform a negative scenario with potential reduction in animal performance, animal health and well-being.

Studies conducted in Chillán, during the 90's decade, demonstrated that a combination of air temperatures greater than $30{ }^{\circ} \mathrm{C}$ and a relative humidity greater than $60 \%$, caused a decrease in reproductive efficiency of Holstein cows in 48\% (Mansilla 1996). In addition, these climatic conditions were negatively associated with milk production during the first one-hundred days of milking (Rodrigo 1996). In Nebraska, USA, Amundson et al (2006) reported a decrease in conception rates at THI greater than 72.9 , but at the same time reported a positive effect of wind speed on conception rate. Similar responses were reported by Morton et al (2007) in Australia. In addition, cows under heat stress have reduced duration and intensity of estrus, altered follicular development, and impaired embryonic development (Jordan 2003).

Another study conducted in Chillán assessed the effect of supplementation supplied to dairy cows under shaded or unshaded conditions during the summer months. The basic diet was a pasture of clover-ryegrass. In this experiment, high air temperatures were positively correlated with rectal temperature in dairy cows exposed to direct solar radiation (Jahn et al 2002). Cows used in this research had a mean milk production of $20.5 \mathrm{~L}^{*} \mathrm{cow}^{-1 *} \mathrm{~d}^{-1}$. The authors reported a decrease in silage dry matter intake in the unshaded treatments, but no statistical differences were reported in milk production. However, there was a trend to higher milk production in the treatment in which the supplement was given concurrently with shade. In addition, the increase in rectal temperature reported by these authors could be confounded with the exposure of animals to direct solar radiation, which was not reported. Studies conducted in New Zealand, with weather conditions that are comparable to those of Southern Chile, have demonstrated that the body temperature of dairy cows is related to air temperature and solar radiation (Kendall et al 2007). The use of shade during temperate summers ameliorated any moderate effect of heat stress on vaginal temperature and milk production (Kendall et al 2006). The previous information agrees with the reports of West (2003), who concluded that the increase of air temperature, THI and the rising of rectal temperature above critical thresholds are related to a decrease in dry matter intake and milk yield.

Potential milk losses reported in this study were lower than those predicted for the central region of Argentina (de la Casa and Ravelo 2003), which has hotter and more humid summers than the regions of Chile studied here. In their study, the authors used the mean THI without adjustment and a lower critical value to estimate milk losses (THI=72). In the present study, the $\mathrm{THI}_{\text {adj-max }}$ and a higher criterion of critical $\mathrm{THI}_{\text {adj-max }}$ were used $\left(\mathrm{THI}_{\text {adj- }}\right.$ $\max =75$ ). Studies conducted in New Zealand by Kendall et al (2006), with weather conditions comparable to those of this study, demonstrated a higher milk production when cows had access to shade. For example, peaks of potential milk production losses estimated for Osorno (figure 4-D) could indicate possible heat waves affecting that particular location.

On the other hand, the study conducted in Chillán in 2002 by Jahn et al (2002) showed no significant decrease in milk production, but milk production was only 20.5 $\mathrm{L}^{*} \operatorname{cow}^{-1 *} \mathrm{~d}^{-1}$. This level of production is not representative of intensive systems. In addition cows were supplemented 
at $1700 \mathrm{~h}$, just after the period of maximum solar radiation. Thus, they did not receive the heat load required to reach a threshold at which the milk production begins to decline. Comparatively, total heat load could have been potentially greater if the supplement had been given to cows earlier in the day. In general, the vulnerability to the effects of heat stress is greater in animals of high levels of production, which are unable to lose the extra heat load resultant from diet and solar radiation. In fact, it is well known that genetic progress in milk production is closely related to increased feed intake, which results in greater metabolic heat load (Kadzere et al 2002). Thus, presumably cows in this study were able to cope with the extra heat load generated from the energy content in the supplement, the energy of digestion and from solar radiation by losing it during night time. In theory, the wider variation of daily temperatures recorded in the locations studied, could allow a better attenuation of heat gained during daytime. Therefore, the extra heat load from the interaction among high-energy diets and climatic conditions should be more important in those locations in Chile, where animals have greater production, consume more energy and produce more heat.

Studies conducted in Central Chile during middle 90's support the results obtained in this study regarding potential reductions in animal performance associated with unfavorable environmental conditions, which not necessarily implies heat stress. A good example of the variability of animal response to the climate, as well as the importance of the index used to quantify its impact on animal production, is observed in the work of Bohmanova et al (2007). The authors conducted a study to determine the threshold of heat stress and rate of decline of milk production associated with a specific THI. In their experiment Bohmanova et al (2007) compared seven THI with different weightings of dry bulb temperature and humidity. The authors concluded that the indices differ in their ability to detect a threshold at which milk production decline begins (ranging from THI = 68 to 84). In similar way, indices differ in rate of decline of milk production per degree of THI (ranging from -0.27 to -0.59 per unit of THI above threshold).

The present study represents a first approach to diagnosing the effects of environmental factors in animal production in Chile, but it has not included any type of productive animal response. The assumption of a similar solar radiation for the calculation of $\mathrm{THI}_{\text {adj-max }}$ constitutes a limitation for the results herein presented, but it was used due to the lack of information of this variable. This is also a reason that justifies the collection of this type of data, because it will allow better estimations of direct impact of the primary environmental factors on animal performance and welfare. It is important to consider that most of the intensive dairy and beef production systems in Chile are located in the Central region of the country, where feedstuffs are easily accessible and include corn, oat, barley and diverse by-products mainly from the horticulture and fruit industry. In addition, calving season in the central region of Chile is all year round. On the contrary, beef and dairy systems in Southern regions are less intensive with some degree of grain supplementation, and have a very marked calving season based mainly on the pasture growing season. These differences, as well as their exceptions should be considered in future studies designed to estimate the direct effects of environment on cattle.

In conclusion, the potential risk of heat stress for lactating dairy cattle is greater in Curicó and Chillán, it is moderate in Temuco and it is minimum in Osorno. The risk of heat stress is greater in the Central region of the country, where the more intensive systems of dairy and beef productions are concentrated. Further research is needed in order to quantify the impacts of environmental conditions on the animal well-being, and to study the direct effects of environmental factors on animal's physiology and productivity under the Chilean production systems.

\section{SUMMARY}

Meteorological data from December to January of years 1999 to 2007 from weather stations located in four localities in Chile (Curicó, Chillán, Temuco and Osorno) were used to calculate the adjusted temperaturehumidity index $\left(\mathrm{THI}_{\mathrm{adj}-\mathrm{max}}\right)$. Climate variables used to calculate the index were: wind speed, air temperature, relative humidity and an estimated value of solar radiation. When the values of $\mathrm{THI}_{\text {adj-max }}$ were greater than 75 , those days were considered as "alert" and as potential risk of heat stress in cattle. Additionally, the impact of climate on animal production was assessed by means of potential losses in milk production for each locality estimated by two equations. The localities of Curicó and Chillán presented similar values of $\mathrm{THI}_{\text {adj-max }}$ (79.4 and 79.1, respectively), and both were higher than those for Temuco and Osorno (77.1 and 68.1, respectively, $\mathrm{P}<0.05)$. The probability of days with mean $\mathrm{THI}_{\text {adj-max }}>75$ was greater in the Central region. In addition, the estimated mean milk production loss was greater in the Central regions (1.5 to 4.3 and 1.2 to $3.1 \mathrm{~L}^{*} \operatorname{cow}^{-1} * \mathrm{~d}^{-1}$ for Curicó and Chillán, respectively). Conversely, the Southern regions, Temuco and Osorno, presented lower potential losses with 0.9 to 2.6 and 0.1 to $0.6 \mathrm{~L}^{*} \operatorname{cow}^{-1} * \mathrm{~d}^{-1}$, respectively. In conclusion, the potential risk of heat stress of cattle seems greater in Curicó and Chillán, moderate in Temuco and minimum in Osorno. Additional research is needed in the order to quantify the impacts of environmental conditions in productivity and welfare of cattle in Chile.

\section{REFERENCES}

Amundson JL, TL Mader, RJ Rasby, QS Hu. 2006. Environmental effects on pregnancy rate in beef cattle. J Anim Sci 84, 3415-3420.

Arias RA, TL Mader, P Escobar. 2008. Factores climáticos que afectan el desempeño productivo del ganado bovino de carne y leche. Arch Med Vet 40, 7-22.

Birkelo CP, DE Johnson. 1993. Seasonal environment, performance and energy metabolism of feedlot cattle in northern Colorado (USA). In: Livestock Environment IV. Fourth Int Symp, Coventry, England, Pp 1117-1124.

Bohmanova J, I Misztal, JB Cole. 2007. Temperature-humidity indices as indicators of milk production losses due to heat stress. J Dairy Sci 90, 1947-1956.

Bouraoui R, M Lahmar, A Majdoub, M Djemali, R Belyea. 2002. The relationship of temperature-humidity index with milk production of dairy cows in a Mediterranean climate. Anim Res 51, 479-491

Collier RJ, GE Dahl, MJ VanBaale. 2006. Major advances associated with environmental effects on dairy cattle. J Dairy Sci 89, 1244-1253. 
de la Casa A, AC Ravelo. 2003. Assessing temperature and humidity conditions for dairy cattle in Córdoba, Argentina. Int J Biometeorol 48, 6-9.

Igono MO, HD Johnson, BJ Stevens, GF Krause, MD Shanklin. 1987. Physiological, productive, and economic benefits of shade, spray, and fan system versus shade for Holstein cows during summer heat. J Dairy Sci 70, 1069-1079.

Jahn E, S Arredondo, W Bonilla, A Del Pozo. 2002. Efecto de la temperatura y la suplementación energética sobre la producción de leche en vacas lecheras a pastoreo. Agricultura Técnica 62, 245-254.

Johnson DE. 1986. Climatic stress and production efficiency. In: Moberg GP (ed). Limiting effects of stress on cattle.Western Regional Research Publication \#009 and Utah State University, Logan, Utah, USA, Pp 17-20.

Jordan ER. 2003. Effects of heat stress on reproduction. J Dairy Sci 86, 104-114.

Kadzere CT, MR Murphy, N Silanikove, E Maltz. 2002. Heat stress in lactating dairy cows: A review. Livest Prod Sci 77, 59-91.

Kendall PE, PP Nielsen, JR Webster, GA Verkerk, RP Littlejohn, LR Matthews. 2006. The effects of providing shade to lactating dairy cows in a temperate climate. Livest Prod Sci 103, 148-157.

Kendall PE, GA Verkerk, JR Webster, CB Tucker. 2007. Sprinklers and shade cool cows and reduce insect-avoidance behavior in pasturebased dairy systems. J Dairy Sci 90, 3671-3680.

LCI, Livestock Conservation Institute. 1970. Patterns of transit losses. Omaha, NE, USA.

Mader TL, JM Dahlquist, JB Gaughan. 1997. Wind protection effects and airflow patterns in outside feedlots. J Anim Sci 75, 26-36.
Mader TL. 2003. Environmental stress in confined beef cattle. J Anim Sci 81, 110-119.

Mader TL, MS Davis, T Brown-Brandl. 2006. Environmental factors influencing heat stress in feedlot cattle. J Anim Sci 84, 712-719.

Mansilla V. 1996. Estudio preliminar de algunas variables climáticas sobre la eficiencia reproductiva en vacas Holstein en la Provincia de Nuble. Memoria de título, Facultad de Medicina Veterinaria, Universidad de Concepción, Chillán, Chile.

Morton JM, WP Tranter, DG Mayer, NN Jonsson. 2007. Effects of environmental heat on conception rates in lactating dairy cows: Critical periods of exposure. J Dairy Sci 90, 2271-2278.

Nienaber JA, GL Hahn. 2007. Livestock production system management responses to thermal challenges. Int J Biometeorol 52, 149-157.

Rodrigo M. 1996. Efecto de la temperatura ambiental, la humedad relativa y la velocidad del viento sobre la producción lechera de vacas Holstein Friesian en el primer tercio de la lactancia. Memoria de título, Facultad de Medicina Veterinaria, Universidad de Concepción, Chillán, Chile.

St-Pierre NR, B Cobanov, G Schnitkey. 2003. Economic losses from heat stress by US livestock industries. J Dairy Sci 86, 52-77.

Thom EC. 1959. The discomfort index. Weatherwise 12, 57-59.

Valtorta SE, PE Leva, MR Gallardo, HC Castro, OE Scarpati. 1999. Producción lechera: Evaluación de dos índices de estrés para analizar impactos ambientales. Actas XI Congreso Brasileiro de Agrometeorología y II Reunión Latinoamericana (SBA), Florianópolis, Brasil, Pp 786-791.

West JW. 2003. Effects of heat-stress on production in dairy cattle. J Dairy Sci 86, 2131-2144. 